\title{
ТРАДИЦИОНАЛНО И МОДЕРНО У ПОЕЗИЈИ РАДОСЛАВА ЗЛАТАНОВИЋА
}

\begin{abstract}
Лирски профил Радослава Златановића обележио је другу половину XX века у српској поезији на Косову и Метохији. Косовски мит и култ жене су у његовој поезији прожети паганским и савременим елементима. Текст прати традиционалне и модерне слојеве ове поезије, који чине лирску симбиозу. Златановић представља екстазу животне радости и младости, по којима је сродан авангардном међуратном српском песнику Растку Петровићу. Ова поезија носи традиционалне архетипске слике, али и модернистички сензибилитет и аутентичну поетску експресију. Лирика овог песника утицала је на формирање читаве генерације савремених српских песника на Косову и Метохији.

Кључне речи: традиционално, модерно, жена, природа, косовски мит.
\end{abstract}

Лирска физиономија Радослава Златановића истакнута је у косовско-метохијској поезији на српском језику, али је значајна и по иманентној припадности матичној српској књижевности 60-тих година претходног века, када је објавио своју прву збирку песама „Додир лета” са Божидарем Милидраговићем. Уз Даринку Јеврић, водећи песник овог поднебља, Златановић је на аутентичан начин оваплотио епски историјски и атавистички садржај везан за традицијске мотиве и митове сублимиране са модерним лирским сензибилитетом и структурним поетским променама. У својој поезији песник је креирао нови статус старог човека који своју архетипску матрицу моделира у додиру с елементима савременог живота и историјских токова. Овај песник је следио традиционалне архетипове који су постојали у делима његових предчасника, косовских писаца Манојла Ђорђевића Призренца, Григорија Божовића и других, али их је у жанру поезије модернистички стилизовао, те представља, уз Лазара Вучковића, родоначелника савремене српске поезије на Косову и Метохији. Упркос чињеници да спаја атавистичка и прошла времена, лирска пројекција Радослава Златановића није историјска ни традиционална, већ надисторијска, чулна и интимистичка. То се нарочито тиче феноменологије косовског мита утемељене на хронотипу Косова и метафизичког

\footnotetext{
${ }^{1}$ andrejevic03@gmail.com
} 
квалитета његове трагике. Архетипским традиционалним обрасцима овог феномена, Златановић је дао индивидуални карактер. Еруптивни лирски таленат овог песника склон је паганском и пантеистичком осећању света и налик „великој екстази” коју је преферирао међуратни авангардиста Растко Петровић. Такав експлозивни модернистички дискурс фундиран је у поезији Златановића традиционалним маркерима унетим у промењену фрагментарну структуру лирског дискурса.

Златановић се у родном крају Косовске Каменице упознао с елементима руралног, фолклорног и натуристичког миљеа народног живота. У својој поезији стварао је сопствени поредак те традиције, уз јако развијену интуицију о њој. Тиме је успео да модернизује и активира архетипске представе у оквиру своје лирске експресије. На фундаменталним основама саборног умља, генске традиције и примордијалне истине, посебно свог наслеђеног номадског племенског ероса (у афирмативном смислу), он је своју слику света пренео на модерну егзистенцијалну раван и представио сензибилитет савременог човека. Најважније карактеристике поезије Радослава Златановића аутор ових редова представио је у раду „Атавистичко и савремено у поезији Радослава Златановића" (Андрејевић, 2009, стр. 275-283), као и у антологији Портрети косовских писаиа (Андрејевић, 1988).

Лирска релација дом-свет и традиција-савременост фузионисана је у сублимну хомогену поезију и оригинални лирски израз овог песника. Аутентичношћу свог поетског израза, Златановић је иновирао лирске хоризонте региона јужне Србије. Сама историја косовског тла, његова суштаственост и судбоносност за српски народ, симбол његовог бића и идентитета, та наша основна земља и најскупља реч српског језика (М. Бећковић) подразумевају нагонску припадност колективном уму и генској меморији у антрополошком и онтолошком смсилу. У случају поезије Радослава Златановића, препознајемо дубоку потребу и мотивацију песника да се традиционални мит Косова укључи у жижу савремених дешавања, јер за Србе свети Грал станује на Косову.

У оквиру ове поезије, може се успоставити лирски паралелизам, осим са српском међуратном авангардом и са једним другим значајним савременим песником Косова и Метохије, поменутим Лазаром Вучковићем и првим српским неосимболистом Бранком Миљковићем. Мада генерацијски близак њима, Златановић, по особинама своје лирске фразе, по посебном поетском наративу, елиптичној лирској причи, потврђује Деридину теорију разлике о различитом присуству песника у свету и изражавању тога присуства. У односу на песнике синхроне његовој појави, у лирској компарацији, више се уочавају особености Златановићеве него сличности с њима. Уопште, српски песници Косова и Метохије су, из историјских и политичких разлога, деценијама били скрајнути из матичног културног простора и недовољно познати сопственом језику и матичној српској књижевности. Отуда њихови 
узори и долазе колико из српске матичне књижевности, толико и из европске и светске поезије коју су прилагођавали феноменологији косовског мита у традиционалном и савременом значењу.

Неке од темељних мотивских и идејних основа поезије Радослава Златановића јесу традиција, природа, косовски мит. Овај последњи је протопоетички и геопоетички уграђен у основе косовског опредељења свих српских песника од Његоша, преко Милана Ракића до данас. Експлицитно или имплицитно, Златановић прати дубоку традиционалну матрицу матерње мелодије, коју је у другом кључу промишљао Момчило Настасијевић, трансформисане у новој лирској експресији и структури. У последње четири деценије нове ратне и поратне кризе на Косову и Метохији, реактивира се и реинкарнира новомитска ситуација на Косову, што утиче на целокупну српску поезију, па и лирику Радослава Златановића. У историји матичне српске књижевности могу се наћи песници заједничари и песници интимисти, гласни и тихи песници, како је говорила Исидора Секулић, који су косовском миту посветили велики број антологијских песама. О косовским песницима и њиховом односу према миту писао је и аутор овог рада у својим књигама и текстовима.

Косовски мит долази из дубина традиције народа и колективно несвесног искуства уметника. Ниједна уметност није тако упорно национална као поезија, записао је Томас Стернс Елиот у свом чувеном есеју „Традиција и индивидуални талент”. Стивен Гринблат говори о новом историзму и културном патриотизму, а Јирген Хабермас одређује национални модернитет као вид осавремењавања колективне свести. Општежиће и саможиће су увек били део културне и цивлизацијске потке једног народа. У стилско-семантичком и естетичко-аксиолошком смислу, традиционална матрица мита свакако обогаћује савремену поезију, јер удаљену језичку ситуацију смешта у жижу савремених збивања и конотира их. Од самог боја, овај мит расте у српској култури преко Његошевог косовског завета (кога је Андрић назвао трагичним јунаком косовске мисли), потом видовданске идеје Исидоре Секулић (1911), Ракићевог косовског циклуса и задужбинског текста „Шта је то косовско опредељење” Зорана Мишића (1961). Потом, Црњански слави косовске цркве, али уз пацифистички отклон и убеђење да из традиције треба узети само најбоље. Ту посвећеност косовском миту, ту естетику негативног исхода историје и пораза („нека буде што бити не може” и „не бојте се, добро бити неће”) Андрић је назвао позитивним нихилизмом.

Златановић је добитник многобројних значајних награда, па и Базјашке повеље у Румунији. Препознат је као чувар баштине коју пројектује модерним сензибилитетом и експресијом. При томе се мотив традиције односи на атавистички, предачки, рурални миље, а савремено и модерно је испољено урбаним еротским визијама жене која је често смештена истовремено 
у пантеистички и традиционални свет. Он пева о комаду земље Косова, о српској ноћној стражи, о тајној вечери у Грачаници, при чему се та знамења косовског мита у овој поезији, кроз транскултурну визуелизацију преносе на савременост. У песми „Нападнута софра” Златановић вели:

На самрти је грачанички отац Инфонт Јовановић

А једнорука игуманија Параскева у Девичу

Пушком и тојагом брани своје животиње

Своју софру, фреске, своје сестре, воћке и њиве

Пребројава одсељене, напуштена огњишта

Куку и леле нама монахињама робињама

Насрнули су црни биволи грифони с изобличеним лицем

И преоравају се кости српских девојчица

У Вучитрну, Мучиврцу и Истоку

Говорник на телевизији лежерно одмахује руком

Попови и српске калуђерице измишљају зла на Косову. (Златановић, 1995: 200)

Почев од пејзажа детињства и породичног окружења, до косовских равница и метохијских винограда, Златановић конституише традиционалан дом као симбол преузет из предања и сопствених успомена. Уколико се подсетимо англоамеричке едукације нашег песника, можемо наћи везе његове поезије и с европским митовима или урбаним савременицима. Златановићеви симболи су блиско примакнути животу и савременом свету, али су сачували своју митску и фантазмагоричну ауру. Јединствени естетички ефекат чини управо утисак да се у његовој поезији та старина дешава управо данас, и да у њој песник учествује као лирски лик. Спој прошле и савремене инсценације живота раван је великој бахтиновској карневализацији света. Ова лирска диорама у поезији Радослава Златановића меша физичко и метафизичко, антрополошко и онтолошко, домољубно и космополитско, културолошко и хедоностичко. Из дубина традиције, ова поезија носи снагу и тековине колективног, које у садашњости еманирају моћ субјективне енергије песника.

Важност атавистичког човека традиције у овој поезији фунционише као вид борбе са савременим судбинским менама и успостављена је у сврху трајања, а против пролазности. Златановић то открива у стиху: „Људи које сам видео не могу остарити". Човек је човек за сва времена, монолит у свету, вертикала косовског хронотопа, axis mundi на својој земљи која је magna mater. Човек је тип и карактер, предак и потомак, манистички субјект његове поезије и виталистички симбол постојања. Зато се у овој поезији јављају и традиционални митски симболи хтонског вука, митолошке змије уробороса и српског прачовека. Песник још живи у колиби, бави се ловом да прехрани жену, туче се батином с њеним удварачима. Та слика преисторијског примитивизма или старословенске прошлости, уз обредне слике и ритуално певање, представља лирску магијску формулу коју ће Златано- 
вић, сублимирати и пребацити у модерне савремене песничке представе. У песми „Неко је наш, сад приказан у пољу” утемељена је лирска слика пантеистичке натуралне средине сред које се пије стара словенска медовина. Историјска подлога Косова је разапета у лирској мрежи с Агеренима, Арнаутима и Турцима, али се о њима у савремености такође пева с истим критичким тоном.

Поетизација факта, естетизација историје и лирски трагизам у поезији Радослава Златановића су ублажени том критичко-ироничном, каткад и хуморном нотом. Сажимање и закривљење времена и постојање песниковог субјективног хроноса чине да се прошло и савремено хомогенизују. Стварносни говор овог песника који се опире конструктивизму и артизму помаже му да повеже традиционалне и савремене песничке слике које, попут Лајбницових монада, узрокују целу структуру и семантику ове поезије. Прачовек и модерни песник су један лирски субјект. Може се рећи да је сам Златановић главно лице сопствене поезије. Уношењем свога имена у лирски текст, он привидно изједначује фиктивну и фактографску стварност и тиме есенцијализује и онеобичава лирски израз.

За Радослава Златановића, „увек негде звоне дечанска звона”, која прате песника и у српским сеобама и расејањима. У својој сјајној, чувеној песми „Грачаничка вечера”, песник у првом стиху каже: „Али ја нећу да певам о њој, ја хоћу да вечерам". Певање припада прошлом сјају, храна садашњем оболу светој грађевини. Песник указује на светост прошлости, али и на величину живота у садашњости која се инкарнира на вечери са јужносрбијанским сељацима из Долома. Златановић вели да „има белих манастира у нашим зеленим долинама, има мудрих калуђера попут Јустина Дечанског”, спајајући традиционалне вредности с текућим дешавањима на грачаничкој вечери. У збирци песама „Викање на стоку”, Златановић се поново бави Доломчанима, али и људима из Риџент парка или Пакистана. Та брза смена дијаде дом-свет једнака је смени традиција-савременост. Песник путује напред и натраг кроз време и простор природношћу која фузионише његове стихове. Златановић тиме еманира свој авантуристички дух и путничку егзистенцију. Након тога, он жури натраг својим Србима, својим Црногорцима, својим Циганима, својој Јужној Морави, као у песми „Певање о родитељима". Песников завет јесте Косовско поморавље, али он цео свет доживљава као завичај.

Однос локалног и универзалног, дијалекта и књижевног говорног обрасца, показује снагу дијахронијског сажимања феномена и сензација у поезији Радослава Златановића. Она има свој јединствени тон, свој епски стих колико и кратку форму, свој лирски наратив као у песми „Време”. Песник носи југ у крви и има „неизговорене речи доброј земљи”. Воли земљу јер она је његово тело. Воли Бога, али и пужа с два рога, као у песми „Море, птицо, стани, збуњујеш ме”. Овакав спој религиозног и пантеистичког ка- 
рактеристичан је за поезију Радослава Златановића, за његов спој традиције и савремености. Песник се дружи са првим човеком који пече мамутово месо и леже поред Еве. Његова је кућа љуљашка на југу, а црквена звона из родног села, боја завичајног цвета су окоснице традиционалних идиома и симбола. У песми „Хвала човеку који се плаши ватре” домицилни елементи - мотика, жито, срп, кућа, ракија, иницирају човека да тугује за родним крајем и да се врати да ту умре. У песми „Више није исто” два стиха одражавају однос традиције и савремености као јединство супротности ових бинарно-опозитних категорија живота. Први је узет из народне поезије „Шта се бели у гори зеленој” и други је песнички - „Јер плови негде моја усијана глава”. Архаични призор породичне сеобе из сјајне песме „Велика недеља" постаје метонимијска сцена за савремени лирски дискурс о изгону. Стих „Ако сам вам показао пут до извора” показује лирски пут ка искону и традицији. "Поредак ове песме удаљава ме од злочина" вели песник, као што синтагма „викање на стоку” указује на живот патријархалне фамилије са критичким алузијама на савремено друштво. Растакање традиције праћено је новом стварношћу негативно измењеног света.

Други пол лирске фасцинације Радослава Златановића који такође спаја традиционално и савремено је његов сјајно остварен мотив љубавне поезије, која слави мит жене и култ тела. Ове песме настањују једре сељанке и путене грађанке, микрокосмичке Косовке и макрокосмичка Жена из универзалне сфере. Песник је први човек који са својом женом Дана осмог посматра свет у свој његовој чистој праформи, с тим што је песник демијург песничке слике. Тај лирски полигенизам представљен је у славу рађања жене и њеног постојања. Виталност љубави између човека и жене визуелизована је библијским сликама међу зверињем, у природи рајског врта или сликама грешног живота у лондонским квартовима. Таква визуелизација и лирска синергија женских фигура показују да је жена за Златановића у ствари топос - традиционално и модерно тело и да одражава цикличне манифестације света. За разлику од Дучићеве химере или Андрићеве Јелене, жене које нема, Златановићева Абвесидора је жена које има, и у традицији и у савремености. Он је заљубљен у најобичнију жену, кад је мало полудео, како каже у песми „Шестог дана”. Жена је axis mundi, светска оса која пресеца свако постојање, као у песми „Нагађање о Изеанемони”. Са женом песник се осећа као да је војска једне државе уз њега. Она је светлост која не може поуздано да се запамти, вели песник.

Када пружи руке планина је ближа

Људи се сете да могу и друкчије да живе

Робијаши пишу молбе за помиловање

Водник Фадил Берберовић

Не може прописно да построји војску

Очеви се чуде шта су родили

А њене су руке као јабуке. 
Она ништа не мора да каже

Цигани ће саковати котао и поклонити јој га

Она треба да носи хлеб у собе болесницима

Она може да посвађа рођену браћу. (Златановић, 1995: 74)

Чак и велики створитељ завиди му на жени, као и сви старци, писци и младићи у песми „Бестидне руке створитеља”. Професор Зоран Павловић пише да из модела жене као архетипа, Абвесидора улази у песму као модеран женски лик (Павловић, 2005: 47). Постоји и колективни женски лик у поезији Радослава Златановића. То су девојке из Обилића, Гњилана, Владичиног Хана, Приштине, које носе ерос епског простора, као у песмама „Курвање Доломчанки” и „Свадба у полому”. Очито је да је друго главно лице ове поезије, уз лирског субјекта самог песника и жена, понекад само тело жене. Она долази из атмосфере средњовековља и силази на улице Приштине. Жена је транслирски медиј, интегришућа сила његове поезије која га дефинише као једног од најбољих песника љубавне поезије у савременој српској лирици. Слика жене у Златановићевој поезији је тако стварносна, а истовремено тако антимиметичка. Ова синкретичка појава представља лирску етногенезу еротске традиције и модерне сексуалне револуције. Златановићева жена је конкретизована, од крви и меса, али је и полифона појава. Она је често у суседству с вољеном реком, Јужном Моравом, која је такође принцип женскости, magna mater и прочишћења. Жена пролази кроз манастирска врата, чува свиње у црквеном дворишту и ради у градском заводу. Тако сензуално посвећен жени, са расном екстазом тела и метастазом осећања, Златановић је близак „великом пијаном физичком животу” Растка Петровића, младићству и религији тела поменутог песника. Та хедонистичка епикурејска снага жене доноси у Златановићевој поезији представу Великог тела које се налази у руралном русоовском и у урбаном окружењу. Слободна еротска жена долази из запретане митологије аутора, како вели Ролан Барт и песник је легитимише као свежену и носиоца свег живота.

Песник добро влада митопоетичком вештином, о чему нам сведочи Радивоје Микић у предговору збирке песама „Грачаничка вечера” Радослава Златановића (Микић, 1975: 17). Ликови жена с необичним лирским именима Абвесидора и Изаенемона „лепших од њива и ливада гиздавих” су натуралистичке, веристичке жене које су симбол живота. Жене у овој поезији, ма како митске појаве, се често налазе и у оквиру модерне лирске гротеске, на рубној тачки људске егзистенције, на маргини друштва и на клупама железничких станица. Абвесидора је Аз, Буки Вједи, она представља прва слова старословенске азбуке, она је азбука живота, сама Ева која долази песнику Адаму да прогласе своју историју ероса и објаву љубави. При томе, у том спајању, песник не осећа грех, већ ослобођење. Жена је владарица и Амазонка, она поседује моћ да врати бившу догађајност и да је активира у савремености. Рељеф њеног тела је путоказ смисла. Она је хипетрофирано 
биће, њено колено је као Балканско полуострво. Она је елементарна сила земље, а у поезији врши функцију средишта и круга постојања.

Ми не читамо глупе

Европске и америчке књиге о сексу

О потенцији и импотенцији

Али кад почнем да скупљам

Плодове по Абвесидорином телу

Предосећам како велики Своритељ

Прекрива руком небеску завесу

И зури на земљу нашу

На кућу нашу

И на кревет наш тврд од абоносовине

Безочно. (Златановић, 1995: 143)

Смела, дрска, слободна, ова поезија уједињује мит земље и мит жене, сублимира њихове представе из исполинских времена, из детињства човечанства и лирски их остварује у овом времену. Златановић сугестивно влада тим клизајућим лирским хронотопом јер се шавови метаморфозе времена не виде, све је садржано у једном лирском таласу којим доминира Жена. Митологизација жене, која се креће непрекинутом бергсоновском траком времена доводи њено постојање из удаљеног хроноса у жижу садашњице. На делу је велика еротска екстаза самог песника суверено уграђена у иманентну лирску сферу Радослава Златановића. Драматичне слике прошлости смењују се, као у огледалу, с новомитским сликама садашње косовске трагедије. Лирски паралелизам - примитивна жена и савремена жена, као два лирска лика у једном, дају изванредну надисторијску пројекцију жене - јунакиње прошлости и садашњости, хероине времена. Та велика, голема жена у поезији Радослава Златановића, уза сву велику лирску оставштину у историји жанра љубавне поезије уопште, остаје препознатљива и сугестивна. Жена у овој поезији је жива и узбудљива визија лепоте, смелости и радости живота. (Зато, вероватно, песник није силовао Вирџинију Вулф).

Базирана на традиционалним кодовима, а артикулисана жестоким модернистичким дискурсом, поезија Радослава Златановића је потпуно аутентична и јединствена творевина. У структури и језичкој организацији текста изненађујућа, зачудна и онеобичена, она не само да је иницирала и утицала на целокупну савремену поезију на Косову и Метохији, већ је постала значајна притока магистралном току матичне српске поезије. 


\title{
Литература
}

Андрејевић, 1988: Д. Андрејевић, Портрети косовских писаща, Приштина: Јединство.

Андрејевић, 2009: Д. Андрејевић, Атавистичко и савремено у поезији Радослава Златановића,

Косовска Митровица: Зборник радова Филозофског факултета, 275-283.

Златановић, 1975: Р. Златановић, Грачаничка вечера, Приштина: Јединство, Октоих.

Микић, 1975: Р. Микић, Песник као пророк и миротвораи (предговор збирци песама Р. Златановића „Грачаничка вечера), Приштина: Јединство, Октоих.

Pavletić, 1986, V. Pavletić, Ključ za tumačenje moderne poezije, Zagreb: Globus.

Павловић, 2005: 3. Павловић, Српска књижевност на Косову и Метохији, Лепосавић: Институт за српску културу.

Ћулафкова, 2002: К. Ћулафкова, Метафизика поезије, Београд: Народна књига.

\section{Danica T. Andrejević}

\section{TRADITIONAL AND MODERN IN THE POETRY OF RADOSLAV ZLATANOVIĆ}

\begin{abstract}
Summary
The lyrical profile of Radoslav Zlatanović marked the second half of the 20th century in the Serbian poetry of Kosovo and Metohija. The Kosovo myth and the cult of woman in his poetry are imbued with pagan and modern elements. This paper follows the traditional and modern layers of this poetry, that make a lyrical symbiosis. Zlatanović represents the ecstasy of life's joy and youth, by which he can be related to the avant-garde Serbian poet between the two world wars Rastko Petrović. His poetry carries the traditional archetypal images, but also the modern sensibility and authentic poetic expression. The poetry of Radoslav Zlatanović influenced the forming of the entire generation of contemporary Serbian poets in Kosovo and Metohija.
\end{abstract}

Key words: traditional, modern, woman, nature, Kosovo myth. 